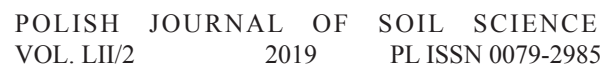

DOI: $10.17951 / \mathrm{pjss} / 2019.52 .2 .269$

\title{
LARISA KUCHER*
}

\section{FORECASTING OF THE IMPACT OF ACIDITY ON THE CONTENT OF MOBILE FORMS OF POTASSIUM IN THE SOILS OF FOREST-STEPPES OF UKRAINE}

Abstract. The level of soil acidity $(\mathrm{pH})$ has the significant impact on availability of potassium to plants. For almost the century, scientists have discussed the issue of acidity of soils. Till nowadays, it is known, that carriers of potential acidity are $\mathrm{H}^{+}$and $\mathrm{AI}^{3+}$ ions, which are situated in the solid phase of soil in the exchanged and absorbed state, but soil solution is acidified as a result of exchange reactions during increase of concentration of electrolytes in it (for example, during application of fertilizes the soil). Our task was to explore the impact of acidity of soil solution on the movement of potassium in some soils of forest-steppes of Ukraine: typical chernozem, podzolized chernozem and meadow chernozem. In the laboratory conditions the soil samples were influenced by citrate-phosphate-borate buffer solution of different volumes of $\mathrm{pH}$ - from 2.8 till 9.5 units, and the potassium content was determined by flame photometry. Based on the research results, there were created mathematical models which predict the potassium content when changing soil acidity. An exponential functional relationship between potassium content in the soil solution and its $\mathrm{pH}$ is established. This functional dependence allows to predict the levels of transition of potassium to the soil solution in the conditions of lowering the $\mathrm{pH}$.

Keywords: typical chernozem, podzolized chernozem soil, meadow chernozem soil, mobile forms of potassium, acidity

* National University of Life and Environmental Sciences of Ukraine, 15 Heroiv Oborony St, Kyiv, Ukraine. Author's e-mail: lora_kucher@ukr.net 


\section{INTRODUCTION}

In today's Ukraine (characterizing with intensive agro-industrial production), one can notice the whole number of problems connected with the soil cover degradation: dehumidification, significant reduction of adding organic and use of physiologically acidic mineral fertilizers, reduction of plantings of siderites and technologically significant predecessors - perennial legumes and leguminous crops, that accumulate biological nitrogen and intensify humus formation, monocultures cultivation, saturation of field rotations of crops by sunflower, rape (which absorbs twice as much nutrients from soil as winter wheat), and, to a large extent, loss of calcium and magnesium which are consumed by plants (Degodyuk 2000). The last factor leads to the change of reaction of soil solution to the direction of its acidification. For example, when $\mathrm{N}_{45} \mathrm{P}_{45} \mathrm{~K}_{45}$ is put as a physiologically acidic ammonium nitrate phosphate fertilizer $(17 \%$ of active substance), the acidification of soil occurs in 3 years on $0.3 \mathrm{pH}$ units (Bronnikova 2016).

As far as potassium in soils is concerned, it is usually found as soluble potassium, exchangeable potassium, non-exchangeable potassium, and potassium in minerals. These forms of potassium are located in a constant dynamic equilibrium with each other (Jalali 2007, Seredina 2013, Gospodarenko et al. 2013). As back as 1912, it was shown the possibility of the transition of non-exchangeable potassium in exchange forms (Pchelkin 1966, Sokolova 1987). In the conditions of vegetative experiment, the cultivated plants on the soil from which exchange potassium was removed, developed in a normal way and there were no visible signs of potassium deficiency. Obviously, stocks of exchangeable potassium were replenished at the expense of non-exchangeable forms.

Soils differ according to the content of the general potassium and the ability to provide potassium to crops under certain conditions (Jalali 2008). The pace of leaching of potassium from soils can have a significant effect on their fertility. The general supply of potassium in the soils of Ukraine is quite large. One hectare of the arable layer of sand sod-podzolic soils is containing 15-20 tons of $\mathrm{K}_{2} \mathrm{O}$, in sod-loam podzolic soil it is $45-75$ tons, in chernozem $-60-75$ tons and in sierozem soils - 75-90 tons. Potassium, adsorptively attached to the surface of colloids (exchange), serves as the main source of plant nutrition. It is no more than $0.5-1.5 \%$ of the total content of this element in the soil. Sometimes, however, potassium is not available for plants.

Microorganisms play the important role in increasing the content of low-soluble potassium compounds in soil. The ability of microorganisms to decompose aluminosilicates was established at the beginning of this century by the Czech scientist J. Szklázáz and Polish microbiologist K. Basalik (Yemtsev and Mishustiin 2005). Later, this phenomenon was confirmed by other researchers. The decomposition of silicates by microorganisms is accompanied by the release of 
acids with a great destructive influence. Acids, which form complex and intracomplex compounds with elements, which are parts of aluminosilicates, characterize with particular solubility. The mucus produced by the microorganisms contains polysaccharides which include uronic acids. They have carboxyl and phenolic groups, which react with certain elements of silicates to form complex bonds, which, in turn, leads to the release of corresponding substance (in this case, potassium) from crystalline lattices and its transition into solution.

In silicate weathering, according to Aristovskaya and Kutuzova, biogenic formation of soda is important. It is shown that nepheline and plagioclase are strongly destroyed under the influence of acids, and quartz by alkalies. Consequently, the decomposition of minerals can take place under the influence of various factors, which is based on acidification (Aristovskaya and Kutuzova 1968).

In Ukraine, there are more than 9 million hectares of acid soils, including 7.6 million hectares of arable land (Kanivets et al. 2000). The amount of soil acidity $(\mathrm{pH})$ plays the important role in the release of potassium from minerals and its leaching in favorable conditions in the lower horizons. The transition of aluminum to solution depends on $\mathrm{pH}$ of soil environment and has parabolic character (Rich 1964). In the acid range, with the values of soil solution from 4.0 to 5.7, aluminum is in the form of ions $\mathrm{Al}^{3+}$, while its amount increases with the decrease in $\mathrm{pH}$. In the range of $\mathrm{pH}$ above 7 , the amount of aluminum increases again due to the domination of aluminate ions $\mathrm{Al}(\mathrm{OH})^{-}$in solution. If soil is acidified by increasing the concentration of hydrogen ions (as a result of destruction of aluminosilicates) aluminum appears as a result of this acidification (Le Roux and Sumner 1968).

Under the natural conditions, acidification of soils occurs mainly according to the biochemical processes, the crucial role in which is performed by microorganisms, plants, organic acids, including humus. According to Tsapko, these are humus acids in soil that perform the most important regulatory role in the process of formation of soil acidity, binding mobile forms of aluminum to strong organo-mineral complex compounds (Tsapko 2000). Additionally, it is not only the upper layer of soil which is acidified, but also root extracts of plants - exudates - which include almost all organic acids of the Krebs cycle, as well as salicylic, cinnamic, chlorogenic acids, methylol, phenylpropionic, 2-furanacrylic acid, which not only change $\mathrm{pH}$ of the soils and increase solubility of minerals, but also affect vital functions of microflora of soil (Pida and Mashkovska 2003).

\section{MATERIALS AND METHODS}

In the study, the samples from the $0-20 \mathrm{~cm}$ layer of zonal soils of forest-steppe zone of Ukraine were selected to examine the effect of acidity on the mobile forms of potassium. These were the following: meadow chernozem soil, 
rough light loam on the loess submerged by the ancient alluvial deposits affected by alkalis (Haplic Chernozem), chernozem soil of typical medium humus and medium loam on the loess (Haplic Chernozem) and podzolized chernozem of medium humus and heavy loam on the loess (Luvic Chernozem). Under laboratory conditions, samples of these soils at a temperature of $20^{\circ} \mathrm{C}$ acted with citrate-phosphate-borate buffer solution of different $\mathrm{pH}$ values in the range of 2.8 to 9.5 units per soil/solution weight ratio 1:5. The content of potassium was determined on the flame photometer (Sokolova 1987).

\section{RESULTS}

For all soils, the content of mobile forms of potassium was the highest at pH 2.8 (Fig. 1). It was obvious that cations $\mathrm{H}^{+}\left(\mathrm{H}_{3} \mathrm{O}^{+}\right)$are capable of displacing potassium cations $\left(\mathrm{K}^{+}\right)$from soil of the soil matrix.

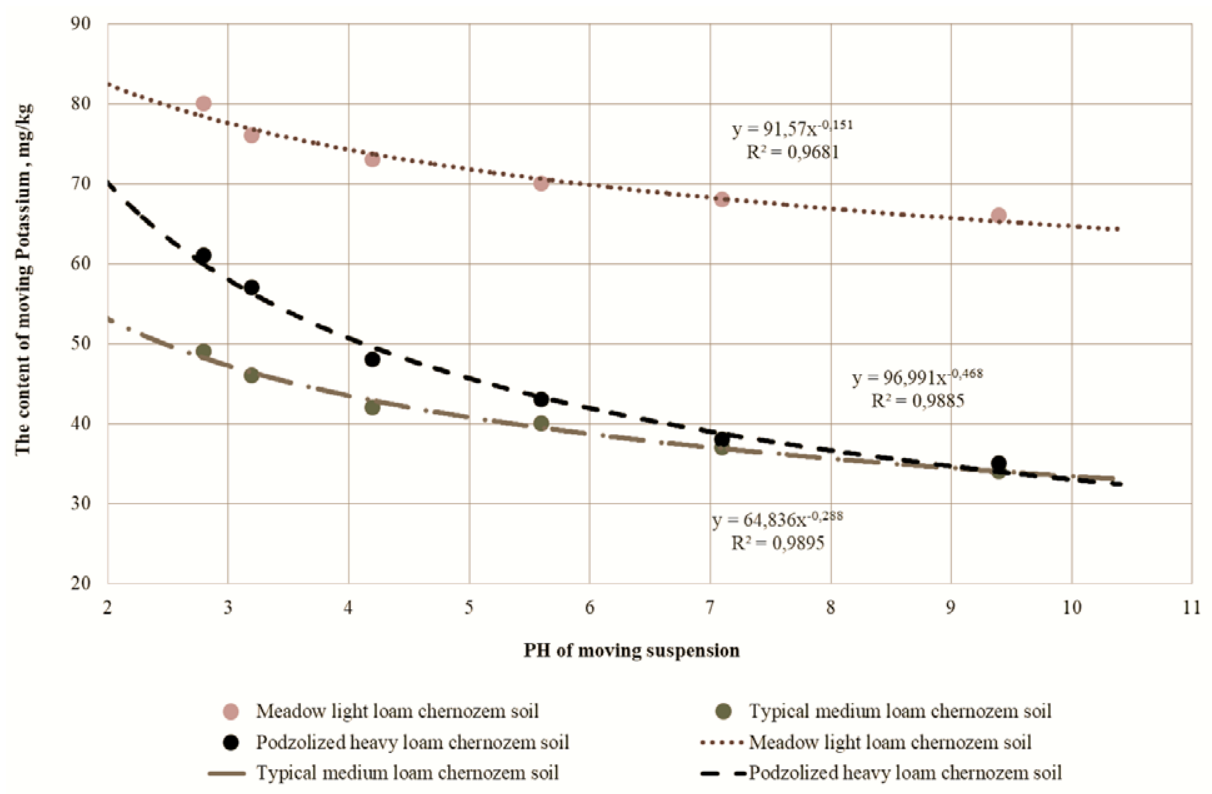

Fig. 1. Dependence of mobile forms of potassium on acidity

The reaction of exchange of cations is carried out according to first-order kinetics and is described by a differential equation of the general form:

$$
\frac{d y}{d x}=-K \times(Y-Y \infty)
$$

Where: $Y$ is the content of mobile forms of potassium, which is moving to the extractor of buffer solution, $\mathrm{mg} / \mathrm{kg} ; X-\mathrm{pH}$ of soil suspension; $Y \infty$ is the 
maximum value of $\mathrm{pH}$ of soil suspension (minimum concentration in suspension of cation $\mathrm{H}_{3} \mathrm{O}^{+}$), at which the growth of mobile forms of $\mathrm{K}^{+}$is still present. That is, at $Y \infty$, the concentration of $\mathrm{H}_{3} \mathrm{O}^{+}$becomes so small that it does not cause displacement of mobile forms of potassium from soil.

After separating the variables in equation (1) we have:

$$
\frac{d y}{(Y-Y \infty)}=-K \times d x
$$

Let us integrate this equation:

$$
\begin{aligned}
& \ln \times(Y-Y \infty)=-K X+C \\
& Y-Y \infty=e^{-k x+c}
\end{aligned}
$$

Consequently, the general solution of equation (1) has the following form:

$$
Y=Y \infty+e^{-k x+c}
$$

Partial solutions of equation (2) serve as a mathematical model for predicting the effect of $\mathrm{pH}$ on the content of mobile forms of $\mathrm{K}_{2} \mathrm{O}$. For meadow chernozem soil, the forecast model has the following form:

$$
Y=65+40.447 e^{-0,3868 x}
$$

The importance of information in Fig. 1 is reflected in Table 1. The coefficients of the linear correlation between $\mathrm{Y}$ experimental and $\mathrm{Y}$ calculated are estimated: $\mathrm{r}=0.99855, \mathrm{r} 2=0.9971$. Standard error correlation coefficient -

\begin{tabular}{|c|c|c|c|c|c|c|}
\hline \multirow{4}{*}{$\begin{array}{c}\mathrm{X} \\
(\mathrm{pH})\end{array}$} & \multicolumn{6}{|c|}{$\mathrm{Y}, \mathrm{mg} / \mathrm{kg}$ (for soils) } \\
\hline & \multirow{2}{*}{\multicolumn{2}{|c|}{$\begin{array}{c}\text { meadow chernozem } \\
\mathrm{Y}=65+40.447 \mathrm{e}^{-0.3868 \mathrm{X}}\end{array}$}} & \multicolumn{2}{|c|}{ typical chernozem } & \multicolumn{2}{|c|}{ podzolized chernozem } \\
\hline & & & $\mathrm{Y}=33+51$ & $15 \mathrm{e}^{-0.4137 \mathrm{X}}$ & $\mathrm{Y}=33+7$ & $44 \mathrm{e}^{-0.3659 \mathrm{X}}$ \\
\hline & $\begin{array}{c}\mathrm{Y} \\
\text { experimental }\end{array}$ & $\begin{array}{c}\text { Y } \\
\text { calculated }\end{array}$ & $\begin{array}{c}\mathrm{Y} \\
\text { experimental }\end{array}$ & $\begin{array}{c}\mathrm{Y} \\
\text { calculated }\end{array}$ & $\begin{array}{c}\mathrm{Y} \\
\text { experimental }\end{array}$ & $\begin{array}{c}\mathrm{Y} \\
\text { calculated }\end{array}$ \\
\hline 2.8 & 80 & 79 & 49 & 49 & 61 & 60 \\
\hline 3.2 & 76 & 77 & 46 & 47 & 57 & 56 \\
\hline 4.2 & 73 & 73 & 42 & 42 & 48 & 49 \\
\hline 5.6 & 70 & 70 & 40 & 38 & 73 & 43 \\
\hline 7.1 & 68 & 68 & 37 & 36 & 38 & 38 \\
\hline 9.5 & 66 & 66 & 34 & 34 & 35 & 36 \\
\hline
\end{tabular}
$\mathrm{S}=0.01268$. Consequently, $\mathrm{r}=0.998 \pm 0.013$. Thus, dependencies are practically functional. They characterize the process of cation exchange, as evidenced by the order of kinetics.

Table 1. Experimental and estimated contents of mobile potassium in soils depending on acidity 
According to American researchers, the exchange of potassium for the ion of hydroxonium is connected with a rapid transfer of the proton of hydrogen bond through water to the places of location of exchange potassium. If there is water between hydrogen and potassium, the exchange takes place rather quickly. Research conducted by Rich (1964) shows that when cation exchange reactions take place and when the hydrated cation diameter is larger, it is the more difficult to exchange small amounts of $\mathrm{K}^{+}$in many soils. Hydrogen cations, even at low concentrations $(\mathrm{pH}=5)$, participate in $\mathrm{K}^{+}$exchange.

The content of mobile forms of potassium in meadow chernozem soil is the highest, because of sufficiently high content of fraction of sand as a result of shaking. There also occurs abrasion of mica particles (hydromicans) (Le Roux and Sumner 1968). This is due to the conditions of formation of such a soil and its genetic peculiarity.

\section{CONCLUSIONS}

The study on the effect of acid solution on mobile forms of potassium in meadow chernozem alkaline soils, typical chernozem soils with medium-humus and podzolized chernozem soil with medium-humus, showed that cations $\mathrm{H}^{+}$ $\left(\mathrm{H}_{3} \mathrm{O}^{+}\right)$are capable of displacing potassium cations $\left(\mathrm{K}^{+}\right)$from the soil matrix. The highest displacement of potassium in meadow chernozem soil is probably due to the relatively high content of the sand fraction, with the shaking of which there occurs abrasion of mica particles.

As can be seen from the study, with acidification of meadow chernozem soil by $0.3 \mathrm{pH}$ units, potassium content increases by $0.52 \mathrm{mg} / \mathrm{kg}$. In typical chernozem, with acidity of soil solution at the 7.1 level, the content of exchangeable potassium is $36 \mathrm{mg} / \mathrm{kg}$, and with the same level of acidification, it increases by $0.07 \mathrm{mg} / \mathrm{kg}$. Podzolized chernozem has $39.2 \mathrm{mg} / \mathrm{kg}$ of mobile forms of potassium under natural conditions, and when acidified, its content is increased by $0.7 \mathrm{mg} / \mathrm{kg}$ of soil.

It was established that the result of the conducted studies is an exponential functional dependence between the content of potassium in soil solution and its $\mathrm{pH}$. This functional dependence allows to predict the levels of potassium transition to the soil solution in case of $\mathrm{pH}$ decreasing.

\section{REFERENCES}

[1] Aristovskaya, T.V., Kutuzova, R.S., 1968. About microbiological factors of mobilization of Silicon hardly soluble natural compounds. Pochvovedeniye, 12: 59-66 (in Russian).

[2] Bronnikova, L.F., 2016. Change in acidity of dark grey forest soil under different technological factors of their use. Agriculture and Forestry, 4. http://repository.vsau.org/getfile. php/16659.pdf (in Ukrainian). 
[3] Degodyuk, E.G., 2000. Ecological problems of agriculture during the $21^{\text {st }}$ century. Materials of all-Ukrainian scientific and practical conference "Agriculture of Ukraine in the $21^{\text {st }}$ century", Kyiv, pp. 4-7 (in Ukrainian).

[4] Gospodarenko, G.M., Nikitina, O.V., Kryvda, I.Yu., 2013. The contents and stocks of mobile forms of potassium in the soil after long application of fertilizers in the field rotation. Bulletin of Sumy National Agrarian University, 11: 51-56.

[5] Jalali, M., 2007. Spatial variability in potassium release among calcareous soils of western Iran. Geoderma, 140: 42-45. DOI: 10.1016/j.geoderma.2007.03.013.

[6] Jalali, M., 2008. Effect of sodium and magnesium on kinetics of potassium release in some calcareous soils of western Iran. Geoderma, 145: 207-215. DOI: 10.1016/j.geoderma.2008.03.005.

[7] Kanivets, V.I., Tokmanova, L.M., Yakimova, V.M., 2000. Liming of leached and acidic soils as an important factor in activating microflora in them and improving phosphoric nutrition of sugar beet. Bulletin of Agrarian Science, 6: 10-13 (in Ukrainian).

[8] Le Roux, J., Sumner, M., 1968. Labile potassium in soils. Soil Science, 106(1): 35-41. DOI: 10.1097/00010694-196807000-00006

[9] Pchelkin, V.U., 1966. Soil Potassium and Potassium Fertilizers. Moscow: Kolos (in Russian).

[10] Pida, S.V., Mashkovska, S.M., 2003. Root exudates: Chemical content, meaning in allelopathy and prospects of use. Agroecological Journal, 3: 45-51 (in Ukrainian).

[11] Rich, C.I., 1964. Effect of Cation Size and pH on potassium exchange in Nason soil. Soil Science, 98(2): 100-106. DOI: 10.1097/00010694-196408000-00005

[12] Seredina, V.P., 2013. Potassium reserves in the soil of the West Siberian plain. The Bulletin of the Tomsk State University. Biology, 1(21): 7-21 (in Russian).

[13] Sokolova, T.A., 1987. Potassium Status of Soils, Methods of Its Estimation and Optimization. Moscow: Moscow University Press (in Russian).

[14] Tsapko, Yu.L., 2000. Regulatory functions of humus acids during the process of soil acid formation. Bulletin of Kherson State Agrarian University, 1: 93-97 (in Ukrainian).

[15] Yemtsev, V.T., Mishustiin, E.N., 2005. Microbiology. Moscow: Drofa (in Russian). 